\title{
The Damaging Effects of Climate Change Denial
}

\section{Rich Snow* and Mary Snow \\ Professors of Meteorology, Embry-Riddle Aeronautical University, USA}

It has been said that those who are denying climate change are like the ostrich that sticks her head in the sand, but is this analogy entirely accurate? By hiding from the threat, does the ostrich make the threat go away, mitigate it, or make it greater? Probably, she does not. However, denying the existence of climate change does exacerbate the problem and exponentially so. As the renowned British economist Nicholas Stern reports, the longer world leaders wait to take serious action to curtail climate change, the more it will cost. As the Chair of the Grantham Research Institute on Climate Change and the Environment, Stern also served as chair of the Centre for Climate Change Economics and Policy (CCCEP) at Leeds University and the London School of Economics. Stern's 700-page report, on the Economics of Climate Change explains the effects that climate change will have on the global economy. Stern calculated that by investing just $1 \%$ of the global gross domestic product (GDP) annually on climate change mitigation and solutions, the world can avoid the higher costs of inaction that will follow inevitably. Stern reworked his analysis a few years after his report was published and advocated a $2 \%$ expenditure of the global GDP on carbon cutting strategies. Stern estimates that without meaningful action to abate climate change, overall costs will be equivalent to losing $5 \%$ of global GDP each year, every year now and into the future. If a broader range of possible repercussions is included, the ensuing impacts could increase this cost to $20 \%$ of the global GDP every year, indefinitely. Stabilization of the climate system would require keeping $\mathrm{CO}_{2}$ emissions between 500 and $550 \mathrm{ppm}$. The global annual average of $\mathrm{CO}_{2}$ for 2014 was 398.55 ppm. For June 2015, that level was $402.8 \mathrm{ppm}$.

The rapid and non-linear increase in the cost of not acting on climate change is partly due to the positive feedback loops that concern climate scientists. The most obvious example of one of these selfperpetuating systems is the melting of Arctic sea ice. Fresh and clean sea ice is an excellent reflector of incoming solar energy. The bright and glossy surface of fresh sea ice can reflect up to $95 \%$ of the energy striking it. The high reflectivity, or high albedo as it is called, serves to cool the planet. When this ice melts, solar energy is not reflected, it is absorbed by the dark blue, choppy surface of the waters of the Arctic region. Absorption of the energy warms the waters, which in turn, melts more sea ice.

Over a 52-year period from 1947-1999, Arctic sea ice lost 3\% of its volume per decade. Since the advent of satellite data in the 1970's, the trend from 1979-2002 was 3\% per decade as well. However, the rate of loss increased in recent years. The measure of the minimum ice extent is measured in September after the summer melt season. The September minimum ice extent currently declines by $12-14 \%$ per decade. In 2007 , the minimum extent declined by more than a million square kilometers of ice, the greatest loss yet recorded. In 2012, a new record low was reached in the extent of the Arctic sea ice. The overall volume of the ice includes the thickness of the ice as well as the areal extent. As a greater percentage of the Arctic ice cap becomes thinner, first-year ice as opposed to the more enduring multi-year ice, the thinner ice is more vulnerable to melting from extratropical cyclones. The storms break up the thinner first-year ice exposing the edges to the wave action and resultant melting from the sea. Of the 18 computer models used by the Intergovernmental Panel on Climate Change (IPCC) to forecast trends in sea ice loss, the melt observed in recent decades is greater than all of them. The loss of ice was analyzed for the effects of wind and temperature. Temperature-forcing accounted for nearly all the loss.

Melting of Earth's cryosphere is not confined to the Arctic. On March 23, 2015, a weather station off the coast of the Antarctic Peninsula broke previous temperature records with a reading of $63.3^{\circ} \mathrm{F}$. The following day, the record was broken again as thermometers read $63.5^{\circ} \mathrm{F}$. At the close of 2014 , researchers reported that the ice sheet of West Antarctica is collapsing faster than anyone predicted. Melting of land-based ice adds to sea level rise. The Antarctic Peninsula has warmed about $2.8^{\circ} \mathrm{C}$ in the past 50 years, while the average warming for Earth as a whole is approximately $0.8^{\circ} \mathrm{C}$ over the past 150 years. The rate of the loss of ice of West Antarctica and Greenland has increased considerably over the last two decades.

The cost of climate change denial is exemplified by other positive feedback mechanisms as well. Beneath the upper layer of soil in the vast Arctic tundra lies permanently frozen soil, or permafrost. Historically, the permafrost has provided a solid and impervious foundation on which the people of this region have constructed their homes, other buildings, and infrastructure. The temperature at the upper limit of the permafrost is around the freeze/thaw point. As this vast region warms, permafrost melts, buildings collapse, pipelines break, streams, fisheries, and communities are polluted, roadways are compromised, and methane is released. A methane molecule $\left(\mathrm{CH}_{4}\right)$ is comprised of a carbon atom and four hydrogen atoms, and it is a potent greenhouse gas. Methane that has been locked up in the permafrost for millennia is released into the atmosphere, and unburned, a molecule of methane has approximately 21 times the global warming capacity as does a molecule of $\mathrm{CO}_{2}$. As Earth's temperatures continue to rise unabated, more permafrost melts, more methane is released, and more warming occurs. Similarly, the warmer average temperatures on Earth contribute to increased evaporation of surface water and soil moisture, as well as more transpiration by plants working to thermo-regulate. Adding water vapor to the air causes further warming since water vapor is an effective absorber of outgoing thermal radiation.

The positive feedback loops are a concern because climate scientists have determined a tipping point, or a point at which changes in the climate system are tipped out of balance. As Kevin Trenberth, climate modeler at the National Center for Atmospheric Research in Boulder, Colorado, explains there is a point at which the climate system goes "non-linear." The tipping point is agreed to be $2^{\circ} \mathrm{C}$ above pre-industrial levels. For the United States, that refers to roughly 1850. If the average

*Corresponding author: Rich Snow, Professor of Meteorology, Embry-Riddle Aeronautical University, USA, Tel: 386-226-7104; E-mail: snow4fc@erau.edu

Received August 01, 2015; Accepted August 05, 2015; Published August 11, 2015

Citation: Snow R, Snow M (2015) The Damaging Effects of Climate Change Denial. J Climatol Weather Forecasting 3: e110. doi:10.4172/2332-2594.1000e110

Copyright: ( 2015 Snow R, et al. This is an open-access article distributed under the terms of the Creative Commons Attribution License, which permits unrestricted use, distribution, and reproduction in any medium, provided the original author and source are credited. 
annual global temperatures exceed the tipping point, forecasting would be far less reliable and severe weather events, far more frequent. Tipping points are considered irreversible and the change in global temperatures can occur abruptly.

The carbon introduced to the atmosphere today will continue to warm the climate system for decades. The ocean, with a high specific heat and ability to store heat without a corresponding temperature rise, has been masking the effects of warming. Additionally, colder ocean water has a greater potential to take up $\mathrm{CO}_{2}$, so as the ocean continues to warm, it will take up less $\mathrm{CO}_{2}$ and both the atmosphere and ocean will warm more quickly. The increased level of $\mathrm{CO}_{2}$ has caused ocean acidification, or a lower value on the $\mathrm{pH}$ scale. Ocean acidification has caused the breakdown of the formation of the shells of foraminifera, tiny sea creatures, who build their shells largely from calcium carbonate. Additionally, the problem of coral bleaching, wherein coral expel the algae that live on them, give them color, and provide their food, is largely attributed to warming ocean temperatures. In light of the enormous costs of denying climate change, why is denial so prevalent and its advocates so emphatic?

A recent example in the state of Florida elucidates the overt nature of denial. In early 2015, officials at Florida's Department of Environmental Protection (DEP) banned the use of the words "climate change," "global warming," and "sustainability" within the department and their communications with the public. A former attorney with the DEP who served from 2008 to 2013 said that was the message communicated to him and his colleagues by their superiors in the Office of General Counsel. Fellow employees at the DEP confirmed that the policy went into effect when the current governor took office in 2011. At that time, the governor appointed a new DEP director. One employee at the Florida DEP was writing a series of fact sheets on coral reefs as part of the Coral Reef Conservation Program. He wanted to include climate change in that series, but was instructed not to. As part of the conservation program, a conference was held in 2014 to train volunteers to construct presentations on coral reef health in Florida. Volunteers were surprised when they were asked not to address climate change when talking about the threats to coral reefs.

A recent analysis conducted by the Union of Concerned Scientists (UCS) evaluated the accuracy of the three most widely watched cable news networks in the coverage of climate science in 2013. The accuracy varied markedly. For one popular news network, $72 \%$ of its climaterelated segments contained misleading statements. Amid the fouryear drought in California, water wars, concerns about increasing rates of malaria and other mosquito-borne diseases, the impacts on communities from more potent storms, tornadoes, hurricanes and floods, and the enormous impacts already occurring on Earth's ecosystems and their stability, there remains the question: Why deny? 